\title{
ISOLATION AND IDENTIFICATION OF ORNITHOBACTERIOSIS FROM BROILER CHICKENS IN NEW VALLEY AND ASSIUT GOVERNORATES
}

\author{
MOHAMED S. ABD EL HAFEZ ${ }^{1}$; MOHAMED KHAMES ${ }^{2}$; SOTOHY AHMED ${ }^{3}$; \\ MOSTAFA A. SHEHATA ${ }^{4}$ AND MOHAMED A. SOLIMAN ${ }^{5}$ \\ 1,2 Birds and Rabbits Diseases Department, Faculty of Veterinary Medicine, New Valley University, Egypt \\ ${ }^{3}$ Animal Hygiene Department, Faculty of Veterinary Medicine, Assiut University \\ ${ }^{4}$ Birds and Rabbits Diseases Department, Faculty of Veterinary Medicine, Assiut University, Egypt \\ ${ }^{5}$ Poultry and fish Diseases Department, Faculty of Veterinary Medicine, Al Minia University, \\ Al Minia 61519, Egypt
}

Received: 4 April 2021; Accepted: 30 April 2021

\begin{abstract}
Respiratory infections are the most dangerous diseases facing poultry industry. Ornithobacteriosis is a respiratory disease in chicken broiler farms, it causes severe economic losses (high condemnation rate at slaughter, high treatment costs). Scientific research papers should be focused on the causative agent in order to make a plan for the ideal steps for its isolation and identification, in addition to prevention and control of this infection. The present work was conducted to isolate and identify Ornithobacterium rhinotracheale (ORT) in chicken broilers. A total of 195 samples (trachea, lungs and air sacs) were collected from dead and sacrificed broiler chickens aged (20 - 42 days old) from different broiler chickens farms in Assiut and New Valley Governorates for possible recovery of ORT. Samples were cultured on blood agar plates under $7.5-10 \% \mathrm{CO}_{2}$ tension at $37^{\circ} \mathrm{C}$ for 48 hours. Bacteriological examination used for isolation and identification of the ORT bacteria (cellular and colonial morphology, biochemical reactions, API 20 NE and growth on MacConkey's agar) showed 32 suspected isolates at percentage of $16.4 \%$. Results of isolation by conventional method were confirmed by molecular identification using Polymerase Chain reaction technique (PCR); which revealed the positive detection of only 5 strains of ORT and produced the predicated 625 bp amplification product. Serotyping of the isolates by using agar gel precipitation test proved that all isolates belonged to serotype A. Challenge of broilers aged 14 days old with ORT strain alone or combined with live ND vaccine by spraying method caused mild respiratory manifestations with tracheitis, pneumonia and mild airsaculitis. While Infection of chicks with ORT via spray combined with prior administration of ND vaccine (stress factor) caused a moderate respiratory signs and more severe lesions. From the results obtained in this work, we can conclude that: The prevalence of ORT infection in broiler chickens in Assiut and New Valley governorates was $2.56 \%$ from living and scarified birds. The current investigation revealed that the isolates of ORT bacteria belonged to serotype A. Post mortem lesions especially yogurt like exudate in the abdominal air sac considered very pathognomonic in the tentative diagnosis of ORT infection. While PCR technique was proved to be more sensitive and specific for detection of ORT pathogen.
\end{abstract}

Key words: ORT, broilers, PCR, challenge

Corresponding author: MOHAMED S. ABD EL HAFEZ

E-mail address: drmohammed.abdelhafez@gmail.com

Present address: Birds and Rabbits Diseases Department, Faculty of Veterinary Medicine, New Valley University, Egypt 


\section{INTRODUCTION}

Chicken meat is an important meat source used by consumers and forms around $36 \%$ of world's meat production. As a result, respiratory diseases are not only a hazard for the producers, but they are also a global economic concern, (Conway, 2017). Respiratory disorders in chickens cause massive economic impacts due to high mortality rates, medication costs, and condemnation rates at slaughter. These infections have been reported all over the world, (Rubio, 2010). Ornithobacterium rhinotracheale (ORT) causes a condition of Ornithobacteriosis, which is a contagious disease spread horizontally by direct contact, aerosols, or indirectly by contaminated drinking water, (Chin and Charlton, 2008). According to World Organization for Animal Health, ORT is a threatening, but not zoonotic microorganism, (Cobb and Smith, 2015).

ORT is highly contagious in various poultry species; the most common affected species are chicken and turkey. ORT is a pleomorphic Gram-negative bacillus organism, has turned into an emerging pathogen in the poultry industry causing significant economic losses (Hafez, 2002).

ORT isolates can grow in various aerophilic conditions. Under microaerophilic environment with $5-10 \% \mathrm{Co}_{2}$ at $37^{\circ} \mathrm{C}$, ideal growth occurs with 5\% sheep blood agar (Van Empel and Hafez, 1999), chocolate agar. Colonies appear as pinpoint clusters $(<1 \mathrm{~mm}$ in diameter) after 24 hours of incubation. After 48 hours; tiny, circular greyish colonies (1-2 $\mathrm{mm}$ in diameter) were identified, sometimes with a reddish glow but frequently with a butyric acid-like odor, (Chin and Charlton, 2008). Eighteen ORT serotypes $(\mathrm{A}-\mathrm{R})$ have been differentiated according to ELISA and agar gel precipitation tests using boiled extract antigens and monovalent antisera. The biochemical tests for the identification of ORT may be confused; Hence, recommended special tests were commonly used to identify ORT such as oxidase $(+)$, catalase $(-), \beta$-galactosidase $(+)$, indole $(-)$ and triple sugar iron agar (no change), (Chin and Charlton, 2008). Serotype A was the most predominant serotype among chicken isolates $(97 \%)$. No relation has been reported between host specificity and the ORT serotype. ORT spreads horizontally by direct and/ or indirect contact. Also, vertical transmission was recorded, (Chin et al., 2008)

The clinical symptoms were mild respiratory signs, that started with sneezing and followed by increased mortality and poor performance. Postmortem findings showed pneumonia and yoghurt like fluids in the abdominal air sacs, (Van Empel and Hafez, 1999).

PCR primers OR16S-F1 (5'- GAGAATT AATTTACGGATTAAG-3'), and OR16SR1 (5'TTCGCTTGGTCTCCGAAGAT-3') have been employed for the identification of a $784 \mathrm{bp}$ fragment on the 16S rRNA gene of ORT, (Van Empel and Hafez, 1999). PCR 784- bp specific ORT DNA fragment was identified in 7 ORT isolates from lungs, air sacs, and tracheas of commercial broilers in Egypt in 2015, (Ellakany et al., 2019).

Microbiological analysis showed that 3 of the 4 farms were positive for ORT. ORT was recorded in 21 birds (32.31\%) out of 65 birds. Agar gel precipitation test showed that all isolates were serotype-A. All strains were positive in PCR by showing a 784 bp amplicon of the 16S rRNA gene, (Umali et al., 2018).

Another study in Assiut Governorate concluded that the prevalence of ORT infection in broiler chickens is $17.77 \%$ using conventional methods, while it is $3.33 \%$ using molecular identification. Serological identification of ORT isolates revealed that all isolates, were serotype A, (Ahmed Hassan et al., 2020) 
Challenge aerosol infection of broilers with three PCR confirmed local isolates of (ORT) from Sharkia Governorate was found to cause growth retardation together with mild respiratory manifestations and 5-10\% mortalities. Mild tracheitis, airsaculitis and pneumonia, (Hegazy et al., 2015).

The aim of the present study was to:

Estimate the prevalence of ORT in broilers in New Valley and Assiut, and investigate the characteristics of the causative agent.

Molecular detection of the suspected isolates in broilers using polymerase chain reaction.

Study the pathogenicity of the isolated strains in broilers.

\section{MATERIALS AND METHODS}

\section{Materials:}

\section{Specimens for surveying ORT infection}

A total of 195 samples (65 lungs, 65 air sacs and 65 tracheas) were obtained from dead and scarified broiler chickens, aged $20-42$ days old from different poultry farms in Assiut and New Valley. All of the examined birds had a history of respiratory signs manifested as cough, sneezing, rales, nasal discharge, conjunctivitis and swollen head. Post-mortem examination showed yogurt like exudate cover the abdominal organs, airsaculitis and pneumonia.

Media used for growing and biochemical identification of ORT:

Media used for cultivation and isolation

Plating solid media; Sheep blood agar, Trypticase soy agar and MacConkey agar

liquid media; Brain heart infusion broth and Trypticase soy broth

Media used for biochemical reactions; oxidase test (oxoide)

Media used for antimicrobial sensitivity; trypticase soy agar and Mueller hinton agar with $10 \%$ sheep blood
Stain; Gram's stain Reagents; 30\% hydrogen peroxide for catalase

Co2 gas bags (Oxoid); used as a source of $\mathrm{Co}_{2}$ for growth of ORT in $\mathrm{Co}_{2}$ jar (Gas pack jar).

Antibiotics added to culturing media; Gentamycin sulphate (Memphis) was added to sheep blood agar as $10 \mu \mathrm{g} / \mathrm{ml}$ media according to Back et al. (1996).

API 20 NE: - It's a strip micro test system (Bio - Mericeux, France) used according to Charlton et al. (1993) and used for detection of the following: -

$\beta$ - galactosidase (ONPG), Arginine dihydrolase (ADH), L- lysine decarboxylase (LDC), Ornithine decarboxylase (ODC), Citrate utilization (CIT), H2S production, Urease (URE), Tryptophan deaminase (TDA), Indol production (IND), Acetoin production (VP), Gelatinase (GEL), Glucose (GLU) oxidation / fermentation, Mannitol (MAN) oxidation / fermentation, Inositol (INO) oxidation / fermentation, Sorbitol (SOR) oxidation / fermentation, Rhamnose (RHA) oxidation / fermentation, Sucrose (SAC) oxidation / fermentation, Melibiose (MEL) oxidation / fermentation, Amygdalin (AMY) oxidation / fermentation, Arabinose (ARA) oxidation / fermentation

Chemicals and reagents used in agar gel precipitation test; $1.5 \%$ nobel agar and $0.1 \%$ thimerosal, phosphate buffer saline (8.5\%) and $0.3 \%$ formaldehyde (PH 7.2) according to Van Empel et al. (1997).

Antisera; antisera of ORT serotype A to G were used.

Experimental birds; A total of fifty ORT free - one day old chicks (Ross).

Strains used for pathogenicity test; ORT isolate of chickens was used.

Materials used for extraction of DNA

a) The QIAamp DNA Mini Kit catalogue no. 51304 
The QIAamp DNA Mini Kit provide silicamembrane- based nucleic acid purification from different types of samples. The spincolumn procedure does not require mechanical homogenization, so total handson preparation time is only 20 minutes

b) Ethanol $90 \%$ Applichem.

Equipment and apparatuses used for extraction of nucleic acids

A- Eppendorf tubes $1.5 \mathrm{ml}$ capacity.

B- Monochannel micropipettes 20-200 $\mu$, 100-1000 $\mu \mathrm{l}$ (Biohit).
C- Sterile filter tips. $(200 \mu \mathrm{l}, 1000 \mu \mathrm{l})$ capacity.
D- Centrifuge (Sigma sartorius).
E- Type II-A bio safety cabinet (Thermo).

\section{PCR Master Mix used for PCR}

Emerald Amp GT PCR master mix (Takara) Code No. RR310 Contains:
A) Emerald Amp GT PCR master mix (2x premix).
B) PCR grade water.

\section{Oligonucleotide primers used in PCR}

They have specific sequence and amplify a specific product, Table (1).

Table 1: Oligonucleotide primers sequences Source: Bibasic (Canada).

\begin{tabular}{llcl}
\hline Target gene & Primers sequences & $\begin{array}{c}\text { Amplified } \\
\text { segment } \\
(\mathrm{bp})\end{array}$ & Reference \\
\hline \multirow{3}{*}{ 16S Rrna } & TGGCATCGATTAAAATTGA & & \\
\cline { 2 - 2 } & AAG & 625 & Doosti et al., 2011 \\
& $\begin{array}{c}\text { CATCGTTACTGCGTGGAC } \\
\text { TAC }\end{array}$ & & \\
\hline
\end{tabular}

DNA Molecular weight marker

Gene ruler 100 bp DNA ladder (cat. no. SM0243)

Supplied from Fermentas.

Number of bands: 10

Size range: $100-1000 \mathrm{bp}$.

Material used for agarose gel electrophoresis

a) Agarose $1.5 \%$ (Sambrook et al., 1989)

b) Ethidium bromide solution $10 \mathrm{mg} / \mathrm{ml}$ (Sambrook et al., 1989).

c) Tris borate EDTA (TBE) electrophoresis buffer (WHO, 2002).

\section{Equipment and apparatuses used in PCR} Calibrated cylinders, Glass flasks, PCR tubes $0.2 \mathrm{ml}$ capacity, Balance (Scaltec), Microwave (Panasonic), Monochannel micropipette (2-20 $\mu$ l) (Biohit), Sterile filter tips, Gel casting apparatus (Biometra), T3 Thermal cycler (Biometra), Power supply (Biometra), Type II A biosafety cabinet.
(Thermo), Gel documentation system (Alpha Innotech), Deionizer (Millipore), Double distillator (Sanyo).

\section{Methods}

Isolation of ORT: Samples (tracheas, lungs, and air sacs) collected under aseptic condition from diseased, scarified and freshly dead broilers and subjected to bacteriological examination. Culture of samples by inoculating brain heart infusion broth for growth and multiplication of suspected ORT organism, incubated for 24 hours at $37^{\circ} \mathrm{C}$ followed by streaking on $10 \%$ sheep blood agar media or tryptic soya agar supplemented with $10 \mu \mathrm{g} / \mathrm{ml}$ of gentamycin sulphate to inhibit the over growth of other microorganisms according to Back et al. (1996). Cultures incubated at $37^{\circ} \mathrm{C}$ for 48 hours under $7.5-10 \% \mathrm{Co}_{2}$ tension by using gas bags (Oxoid) in candle jar. Then examined for suspected ORT colonies. Positive samples suspected to be ORT 
bacteria were inoculated into MacConkey's agar.

\section{Identification of isolated microorganism colonial and cellular morphology}

The suspected colonies were examined for their colonial morphology (shape, size, color and appearance). Films were prepared from the suspected pure colonies and stained with gram's stain, then examined microscopically.

Biochemical Identification: The suspected isolates of ORT were tested biochemically by oxidase and catalase tests beside another identification methods API 20 NE.

Serological Identification: using Agar Gel Precipitation (AGP)

\section{Molecular Identification using Polymerase chain reaction (PCR)}

\section{I) Extraction of DNA according to} QIAamp DNA mini kit instructions

$20 \mu$ QIAGEN protease were pipetted into the bottom of a $1.5 \mathrm{ml}$ microcentrifuge tube. $200 \mu \mathrm{l}$ of the sample was added. $200 \mu \mathrm{l}$ buffer AL were added to the sample, mixed by pulse vortexing for 15 seconds. The mixture was Incubated at $56^{\circ} \mathrm{C}$ for $10 \mathrm{~min}$. The $1.5 \mathrm{ml}$ microcentrifuge tube were centrifugated to remove drops from the inside of the lid. $200 \mu$ l ethanol (96\%) were added to the sample, and mixed again by pulse vortexing for 15 seconds. After mixing, the $1.5 \mathrm{ml}$ microcentrifuge tube was briefly centrifugated to remove drops from the inside of the lid.

The mixture from step 6 was carefully applied to the QIAamp mini spin column (in a $2 \mathrm{ml}$ collecting tube) without wetting the rim. the cap was closed, and centrifugated at $8000 \mathrm{rpm}$ for $1 \mathrm{~min}$. The QIAamp mini spin column was placed in a clean $2 \mathrm{ml}$ collection tube, and the tube containing the filtrate was discarded.

The QIAamp mini spin column was carefully opened and $500 \mathrm{ml}$ buffer AW1 were added without wetting the rim. The cap was closed, and centrifugated at $8000 \mathrm{rpm}$ for $1 \mathrm{~min}$. The QIAamp mini spin column was placed in a clean $2 \mathrm{ml}$ collection tube, and the tube containing the filtrate was discarded. The QIAamp mini spin column was carefully opened and $500 \mathrm{ml}$ buffer AW2 were added without wetting the rim. The cap was closed, and centrifugated at full speed for $3 \mathrm{~min}$.

The QIAamp mini spin column was placed in a new $2 \mathrm{ml}$ collection tube and the old collection tube was discarded with the filtrate. Centrifugation at full speed for 1 min was done.

The QIAamp mini spin column was placed in a clean $1.5 \mathrm{ml}$ microcentrifuge tube, and the collection tube containing the filtrate was discarded. The QIAamp mini spin column was carefully opened and $100 \mu$ l buffer AE were added. The QIAamp mini spin column was Incubated at room temperature (15$25^{\circ} \mathrm{C}$ ) for $1 \mathrm{~min}$, and then centrifugated at $8000 \mathrm{rpm}$ for $1 \mathrm{~min}$.

II) Preparation of PCR Master Mix according to Emerald Amp GT PCR mastermix (Takara) Code No. RR310A kit as shown in table (2): 
Table 2: Preparation of PCR Master Mix.

\begin{tabular}{ll}
\hline Component & Volume /reaction \\
\hline Emerald Amp GT PCR mastermix (2x premix) & $\mathbf{1 2 . 5} \boldsymbol{\mu l}$ \\
\hline PCR grade water & $\mathbf{5 . 5} \boldsymbol{\mu l}$ \\
\hline Forward primer $(20 \mathrm{pmol})$ & $\mathbf{1} \boldsymbol{\mu l}$ \\
\hline Reverse primer $(20 \mathrm{pmol})$ & $\mathbf{1} \boldsymbol{\mu l}$ \\
\hline Template DNA & $\mathbf{5} \boldsymbol{\mu l}$ \\
\hline Total & $\mathbf{2 5} \boldsymbol{\mu l}$ \\
\hline
\end{tabular}

III) Cycling conditions of the primers during PCR

Temperature and time conditions of the primers during PCR are shown in Table
(3) according to specific author and Emerald Amp GT PCR master mix (Takara) kit

Table 3: Cycling conditions of the different primers during PCR

\begin{tabular}{llllll}
\hline Target gene & $\begin{array}{l}\text { Primary } \\
\text { den. }\end{array}$ & Sec. den. & Ann. & Ext. & Final ext. \\
\hline 16S rRNA & $94^{\circ} \mathrm{C}$ & $94^{\circ} \mathrm{C}$ & $60^{\circ} \mathrm{C}$ & $72^{\circ} \mathrm{C}$ & $72^{\circ} \mathrm{C}$ \\
& 5 min. & $30 \mathrm{sec}$. & $45 \mathrm{sec}$. & $45 \mathrm{sec}$. & $10 \mathrm{~min}$. \\
\hline
\end{tabular}

IV) DNA Molecular weight marker

The ladder was mixed gently by pipetting up and down. $6 \mu$ of the required ladder were directly loaded.

\section{V) Agarose gel electrophoreses} (Sambrook et al., 1989) Electrophoresis grade agarose $(1.5 \mathrm{~g})$ was prepared in $100 \mathrm{ml}$ TBE buffer in a sterile flask, it was heated in microwave to dissolve all granules with agitation, and allowed to cool at $70^{\circ} \mathrm{C}$, then $0.5 \mu \mathrm{g} / \mathrm{ml}$ ethidium bromide was added and mixed thoroughly.

The warm agarose was poured directly in gel casting apparatus with desired comb in apposition and left at room temperature for polymerization.

The comb was then removed, and the electrophoresis tank was filled with TBE buffer. Twenty $\mu \mathrm{l}$ of each PCR product samples, negative control and positive control were loaded to the gel. The power supply was $1-5$ volts $/ \mathrm{cm}$ of the tank length. The run was stopped after about 30 min and the gel was transferred to UV cabinet. The gel was photographed by a gel documentation system and the data was analyzed through computer software.

Challenge test: A total number of fifty (one-day old Ross) broiler chicks were reared 35 days in clean well-ventilated house, feed and water were provided ad libitum. Chicks were vaccinated with Hitchner B1 at the $5^{\text {th }}$ day of age via eye drop method. At $10^{\text {th }}$ day of age; the chicks were separated into three equal groups 15 birds each. Five birds were checked for absence of ORT signs and lesions. Chicks of the first group were vaccinated with a coarse spray of Newcastle disease (ND) vaccine, Lasota strain containing $10^{6}$ EID 50/bird at the $10^{\text {th }}$ day of age. Challenge was conducted 
at $14^{\text {th }}$ day of age. Birds were sprayed by $100 \mathrm{ml}$ of BHI broth containing $10^{9}$ $\mathrm{CFU} / \mathrm{ml}$ of ORT isolate using a commercial sprayer after Amal, (2002). The second group was artificially infected with ORT isolate without prior administration of ND vaccine. The third group was kept as control (not infected). All groups were kept under observation for 3 weeks, clinical signs were reported daily. Birds were sacrificed at 7 and $14^{\text {th }}$ days post infection and samples were subjected to post mortem and bacteriological examination.

\section{RESULTS}

\section{Results of isolation and identification of ORT organisms.}

130 samples showed colonies (ranged from 1-3 mm after 48 hours) out of 195 samples on blood agar. They appeared as small circular gray to white opaque and non-hemolytic with distinct odor similar to that of butyric acid. These colonies were cultured on MacConkey's agar. 70 out of 130 samples showed growth on MacConkey's agar. The other 60 isolates which showed no growth on MacConkey's agar (suspected ORT isolates) were subjected to further biochemical reactions.

Morphological properties appeared as gram negative, pleomorphic, sometimes appear in clusters or single plump short rods, non-motile and non-sporulated bacterium.

32 out of 60 tested isolates of ORT were positive for oxidase test and negative for catalase test.

Table 4: API 20 NE strip interpretation.

\begin{tabular}{ll}
\hline Biochemical test & Ornithobacterium rhinotracheale \\
\hline$\beta$ - galactosidase (ONPG) & + \\
\hline Arginine dihydrolase (ADH) & + \\
\hline L- lysine decarboxylase(LDC) & - \\
\hline Ornithine decarboxylase (ODC) & - \\
\hline H2S & - \\
\hline Urease & + \\
\hline Nitrate reduction & - \\
\hline Indole & - \\
\hline Voges - Praskauer (VP) & + \\
\hline Gelatin liquefaction & + \\
\hline Sugar fermentation & - \\
Glucose & - \\
\hline Mannitol & - \\
\hline Inositol & - \\
\hline Sorbitol & - \\
\hline Sucrose & + \\
\hline Arabinose & + \\
\hline Lactose & + \\
\hline Fructose & + \\
\hline Galactose & + \\
\hline Maltose & + \\
\hline &
\end{tabular}




\section{Molecular Identification \\ using Serotyping of the ORT isolates \\ Polymerase chain reaction (PCR) \\ Agar gel precipitation test with specific \\ Ten suspected ORT isolates were selected for PCR assay. According to molecular characterization 5 out of 10 ORT isolates antisera against ORT serotypes A, B, C, D, $\mathrm{E}, \mathrm{F}$, and $\mathrm{G}$ showed that all tested 5 isolates belonged to serotype $\mathrm{A}$} were produced $625 \mathrm{bp}$ amplification product,

fig. (2)

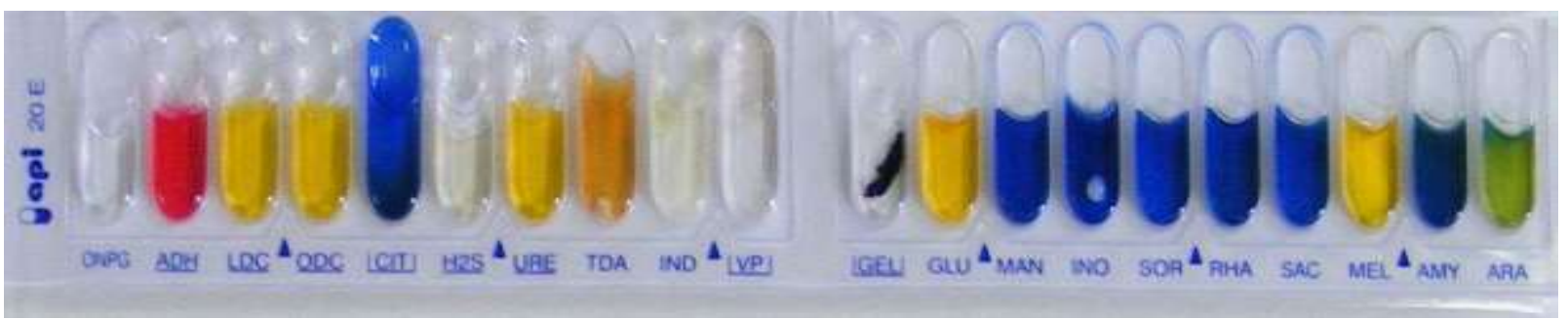

Fig. (1) Biochemical reaction of ORT using API 20 NE.

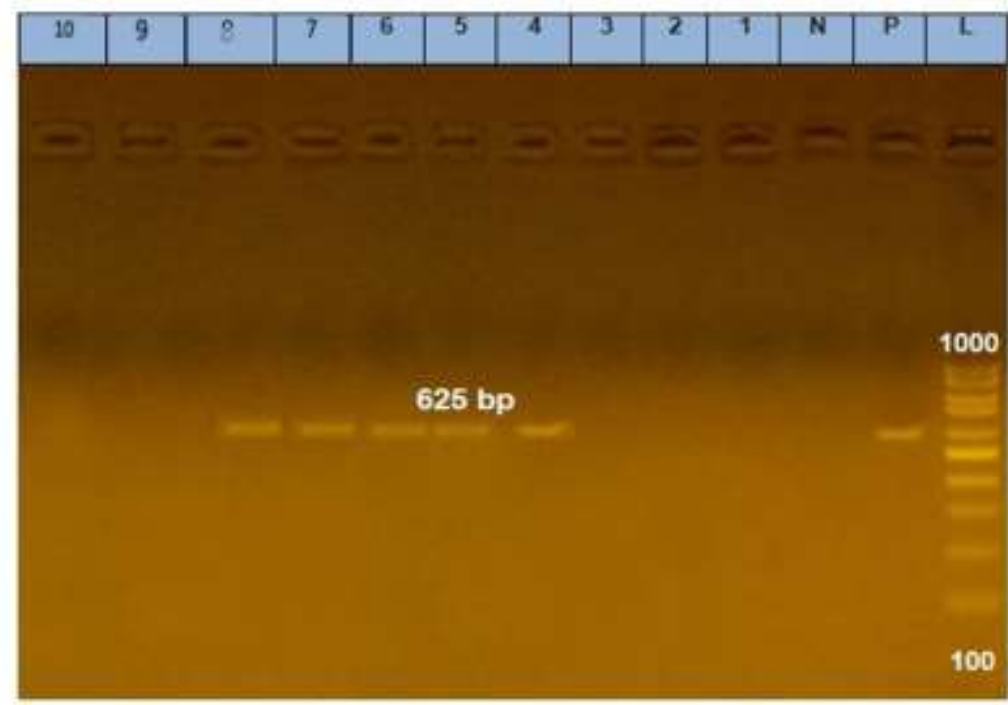

Fig. (2) An agarose gel stained with ethidium bromide, with PCR products of ORT isolates (M:100 bp DNA ladder)

Challenge test: Results of artificial infection with ORT through spray exposure at 2 weeks-old chicks revealed that the first group of broilers which was previously exposed to ND vaccine displayed general signs of huddling together, ruffled feathers, nasal discharge conjunctivitis and slight swelling of the head. Depression and decrease appetite with no mortality.
Lesions of sacrificed birds at 7 days post infection were sinusitis and tracheal congestion while at 14 days post infection there were moderate tracheitis, bilateral pneumonia and moderate airsaculitis with fibrinous airsaculitis were also noticed. Fig. (3) 


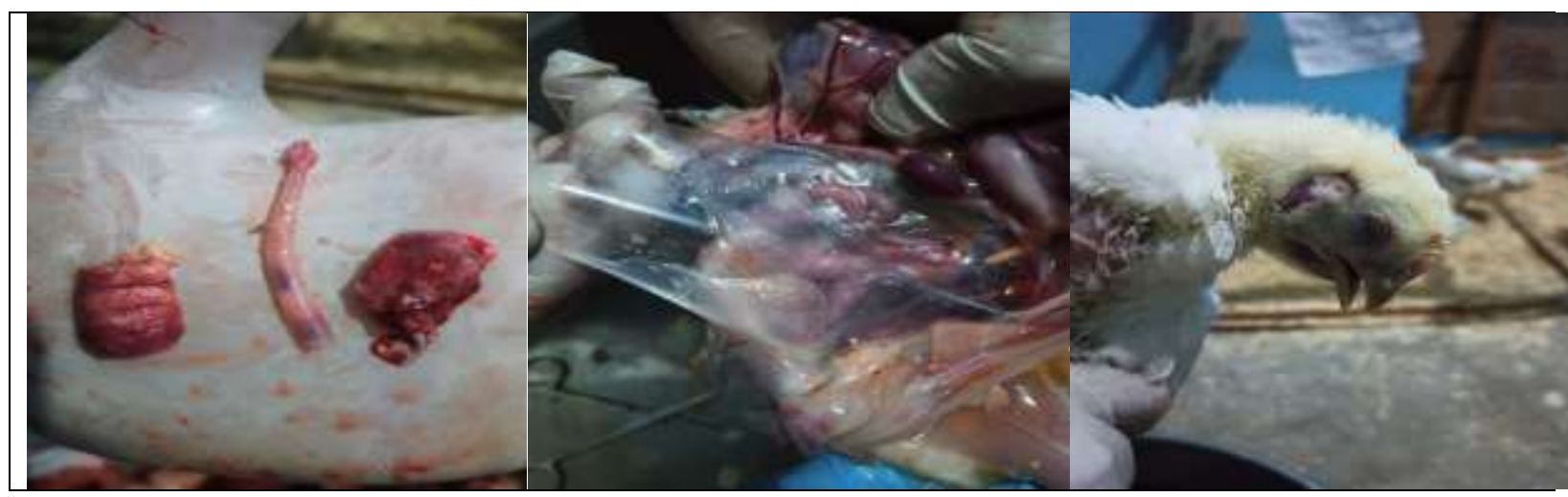

Fig. (3) Showing mild inflammation of trachea, lung and air sacs associated with respiratory signs.

The second group infected with ORT showed nasal discharge, decrease water and feed consumption, depression. Sneezing with slight conjunctivitis. At $14^{\text {th }}$ days post infection there was slight sinusitis, mild tracheitis and mild airsaculitis. The control group did not express any clinical or pathological lesions. At the end of the pathogenicity trial; no mortality was recorded in all groups.

\section{DISCUSSION}

Respiratory disorders in poultry have sanitary and economic impacts, especially in our developing countries (Ellakany et. al., 2018). Several microorganisms remain always incriminating in this case; Mycoplasma gallisepticum, Pasteurella multocida, Avibacterium paragalinarum, Escherichia coli, Riemerella anatipestifer, Bordetella avium and other agents, (Barbosa et al., 2020).

Tentative diagnosis which depends on clinical signs and lesions is of a little value, because many other infectious agents can cause similar clinical picture and postmortem lesions (Hafez and Sting, 1996). Precise diagnosis must be corroborated by isolation and identification of the etiological organisms. Between avian species, an emerging bacterial respiratory pathogen in chickens was observed in South Africa which named Ornithobacterium rhinotracheale (Vandamme et al., 1994). And incriminated as a possible additional causative agent in respiratory disease complex (ElGohary and Awaad, 1998). ORT is a bacterium causing respiratory tract infection, has led to significant troubles in the intensive poultry production in Egypt (Ellakany et al., 2018). This study was conducted to isolate and identify ORT in broiler chickens, it was isolated in our study from different organs as lungs, air sacs and tracheas as reported by other authors (EI-Gohary and Awaad 1998, Amal 2002, Rahimi and Banani 2007 and Mayahi et al., 2016).

EI-Gohary and Awaad (1998) recommended that air sacs, lungs and tracheas were the most suitable organs for primary isolation from respiratory infections. In this study, 195 samples were gathered from different broiler farms in Assiut and New Valley Governorates that suffered from respiratory manifestations; such nasal discharge, coughing, wet eyes sometimes with lacrimation and sinusitis. These findings were described by several authors (EI-Gohary and Awaad, 1998, 
Amal 2002; Canal et al., 2005, Rahimi and Banani 2007 and Asadpour et al., 2008). It was described that the organism is slowly growing and needs longer incubation period (Amal, 2002). The successful isolation of ORT in present study may be attributed to the addition of gentamicin to the medium, which was effective in suppression of contaminating bacteria as shown that most of ORT isolates are resistant to gentamicin, (Back et al., 1997). The current study showed that colonies of ORT on blood agar under $\mathrm{Co}_{2}$ tension were gray to grayish white, opaque, circular, convex butyrous, sometime with reddish glow and always with distinct odor of butyric acid. These findings matched with (Amal 2002 and Shahata et al., 2006). ORT colonies were not hemolytic on blood agar, but some isolates can cause incomplete hemolysis especially after 96 hours, they also grew on BHI broth and trypticase soya agar but not on MacConkey agar, these characters were also mentioned by previous studies (Amal 2002, Asadpour et al., 2008 and Mayahi et al., 2016). In the present study, biochemical tests revealed that ORT isolates were catalase negative and oxidase test positive and these findings matched with (EI-Gohary and Awaad, 1998, Chin and Charlton 2008 and Ellakany et al., 2018). Also, the result of API $20 \mathrm{NE}$ strips of the ORT isolates agrees with (Amal 2002, Canal et al., 2005 and Chin and Charlton 2008).

In our work 10 of our suspected isolates were tested by PCR that is well-thoughtout to be a useful laboratory tool for the definitive identification of suspected ORT isolates, due to difficulty in isolation and biochemical characterization as it is usually overgrown by other bacteria (Chansiripornchai et al., 2007, Chin et al., 2008 and Churria et al., 2011). PCR, which is a sensitive, fast and specific method to characterize and identify such bacterial strain (Hung and Alvarado, 2001, Ozbey et al., 2004 and Hassanzadeh et al., 2010). The results appeared the positive detection of five ORT isolates came in line with (Banani et al., 2009, Li and Diao, 2009, Wu et al., 2010 and Ellakany et al., 2018).

Our present study revealed that 32 isolates of ORT from broiler chickens in Assiut and New Valley Governorates according to isolation and phenotypic identification with incidence of $16.4 \%$, while according to PCR the incidence was $2.56 \%$. These results more or less with in accordance with these reported by (El-Gohary and Awaad, 1998) 8.6\%, (El-Gohary et al., 1998) 4.3\%, (ElGohary and Sultan, 1999) $3.2 \%$, (Amal 2002) 5.8\%, (Elbestawy, 2010) 7.27\%, (Mousavi et al., 2012) 10\%, (Ellakany et al., 2018) $11.66 \%$ and Ahmed Hassan (2020) $3.33 \%$ respectively.

ORT was identified from 3 out of 300 total tissue samples; generated amplification products of $784 \mathrm{bp}$ after the PCR with specific primers, (Mohammad Hassan Zadeh et al., 2010). Moursi and Kawther (2008) estimated that 27 out of $115(23.47 \%)$ were positive for isolation of O. rhinotracheale (16/64 from broilers $25 \%$ and $11 / 51$ from broiler breeders $21.56 \%)$.

Bacteriological examination detected 24 isolates $(12 \%)$ of ORT were isolated from the examined birds. Trachea, lungs, air sacs and sinuses were involved. No ORT was isolated from liver. Serotyping of ORT with AGPT proved that all the isolates were serotype A, (EL-banna et al., 2008). 
So; PCR identification was more sensitive in accurate diagnosis of ORT infection in broiler flocks than the morphological picture and biochemical reactions.

The five PCR positive isolates of ORT were subjected to serotyping using agar gel precipitation test with specific antisera against ORT serotypes, and the results explained that all tested isolates were belonged to serotype A and these results were also noticed by (Amal 2002, Chin and Charlton 2008 and $\mathrm{Wu}$ et al., 2010). Many studies mentioned that serotype A has been found to be the most prevalent serotype among chicken strains (97\%) (Van Empel et al., 1997, Amal, 2002 and Chin et al., 2008).

In the present study, the challenge by ORT isolate was evaluated by aerosol exposure in 2 weeks old broilers. In broilers of group 1, signs appeared to be exacerbated by prior administration of ND vaccine. Clinical signs appeared as depression, ruffled feather, and respiratory signs in the form of conjunctivitis, labored respiration, sneezing and nasal discharge, facial swelling and decreased feed and water intake. Regarding the PM picture, there were severe pneumonia, airsaculitis and tracheitis. These data matched with Amal (2002) and Ellakany et al. (2018), who found that vaccination stress caused higher degree of pathogenicity and severe growth retardation than the single infection of ORT. In group 2, the ORT infection alone caused only mild respiratory manifestations with no mortality, mild to moderate gross lesions in the respiratory system such as mild tracheitis and mild to moderate airsaculitis. This result was noticed by (Amal 2002, Hegazy et al., 2015,
Ellakany et al., 2018 and Ellakany et al., 2019).

Artificial infection of 4 weeks old chickens via intravenous, intra-tracheal and intra-air-sac resulted in decrease in feed consumption and retardation of growth with depression, difficult breathing, conjunctivitis, sneezing, nasal discharge followed by facial edema. Postmortem findings were tracheitis, arisaculitis, pneumonia, pericarditis, and perihepatitis, caseated material in air sac. Mortality was reported in two birds only (13.33\%) after intravenous inoculation. (Moursi and Kawther, 2008).

No mortalities were reported in all groups. However, under field conditions, the severity of the ORT infection's clinical signs, duration of the disease and mortality were extremely variable; they were affected by many environmental factors such as poor management, inadequate ventilation, high stocking density, poor hygiene, poor litter condition, concurrent diseases, variable ammonia levels and types of secondary infection (Naser, 2017 and Ellakany et al., 2018), and the challenged bacteria could easily be re-isolated from the affected organs as found by (Amal 2002 and Shahata et al., 2006).

\section{REFERENCES}

Ahmed K. Hassan; Mennat-Allah Medhat; Mostafa A. Shehata and Aml A. Bakheet (2020): Phenotypic and Molecular Characterization of Ornithobacterium rhinotracheale Isolates in Broiler Chickens. J. Adv. Vet. Res., 10 (4), 193-199.

Asadpour, Y.; Bozorgmehrifard, M.H.; Pourbakhsh, S.A.; Banani, M. and Charkhkar, S. (2008): Isolation and identification of Ornithobacterium 
rhinotracheale in broiler breeder flocks of Guilan province, north of Iran. Pak. J. Biol. Sci. 11(11), 14871491

Amal, A.M.P. (2002): Preliminary studies on Ornithobacterium rhinotracheale infection in Poultry in Upper Egypt. Thesis, M. V. Sc., thesis Assiut University, Egypt.

Back, A.; Nagaraj, K.V. and Halvorson, B.D. (1996): Preliminary studies on Ornithobacterium rhinotracheale. In Proceedings of the Turkey ORT Symposium. September 4 6. Minne. apolis, Minnesota, pp. 29-31.

Back, A.; Staphanie, S.; Rajashekara, G.; Halvorson, $D$. and Nagaraga, $K$. (1997): Antimicrobial sensitivity of Ornithobacterium rhinotracheale isolated from different geographic locations. 48th North Central Avian Disease Conference, 22-24.

Banani, M.; Pourbakhsh, S.A.; Erami, M.; Gholamin, F. and Fatehmanesh, M. (2009): Diagnosis of Ornithobacterium rhinotracheale using polymerase chain reaction (PCR). Journal of Veterinary Research. 64(1).

Barbosa, E.V.; Cardoso, C.V.; Silva, R.D.C.F.; Cerqueira, A.D.M.F.; Liberal, M.H.T. and Castro, H.C. (2020): $\quad$ Ornithobacterium rhinotracheale: An Update Review about An Emerging poultry pathogen Veterinary Sciences, 7(1),3.

Canal, C.W.; Leão, J.A.; Rocha, S.L.S.; Macagnan, M.; Lima-Rosa, C.A.V.; Oliveira, S.D. and Back, A. (2005): Isolation and characterization of Ornithobacterium rhinotracheale from chickens in Brazil. Res. Vet. Sci. 78:225-230.

Charlton, B.; Channings-Santagio, S.; Bickford, A.; Cardona, C.; Chin, R.; Cooper, G.; Droual, R.; Jeffrey,
J.; Meteyer, C.; Shivaprasad, $H$. and Walker, R. (1993): preliminary characterization of a pleomorphic Gram-negative rod aassociated with avian respiratory disease. Journal of Veterinary Diagnostic Investigation $5,47 \pm 51$.

Chin, R.P. and Charlton, B.R. (2008): Ornithobacteriosis. In A Laboratory Manual for the Isolation, Identification, and Characterization of Avian Pathogens, 5th ed.; Dufour-Zavala, L., Swayne, D.E., Glisson, J.R., Pearson, J.E., Reed, W.M., Jackwood, M.W., Woolcock, P.R., Eds.; The American Association of Avian Pathologists: Madison, WL, USA, pp. 75-76. ISBN 978-0-9789163-29.

Chin, R.P.; Van Empel, P.C.M. and Hafez, H.M. (2008): Ornithobacterium rhinotracheale infection, In: Saif Y.M., Fadly A.M., Glisson J.R., McDougald L.R., Nolan L.K., and Swayne D.E. (eds.), Diseases of poultry, 12th ed. Blackwell Publishing Ltd., Oxford, United Kingdom, pp. 765- 774.

Chansiripornchai, N.; Wanasawaeng, W. and Sasipreeyajan, J. (2007): Seroprevalence and identification of Ornithobacterium rhinotracheale from broiler and broiler breeder flocks in Thailand, Avian Dis. 51,777-780.

Churria, C.D.G.; Sansalone, P.L.; Vigo, G.B.; Sguazza, G.H.; Machuca, M.A.; Origlia, J.A. and Petruccelli, M.A. (2011): Pneumonia in chicken broilers flocks associated with $\beta$ hemolytic Ornithobacterium rhinotracheale infection. Braz. J. Vet. Pathol, 4,243-246.

Cobb, S.P. and Smith, H. (2015): The spread of non, O.I.E-listed avian diseases through international trade 
of chicken meat: An assessment of the risks to New Zealand. Rev. Sci. Tech. Off. Int. Epiz., 34, 1-44

Conway, A. (2017): Meat Production: Poultry meat production up 13 million metric tons by 2026. Fig2, Global meat production by species. Poult. Trends, 2017, 22-23

Doosti, A.; Sharifzadeh, A.; Ghasemi, H. and Vaez, J. (2011): Molecular identification of Ornithobacterium rhinotracheale in turkeys in Isfahan province of Iran. African Journal of Biotechnology, 10(40): 7911-7914.

El-Banna, H.I.R.; Masoud, E.A. and Rizk, M.K. (2008): Some studies on Ornithobacterium rhinotracheale infection in broiler flocks at Sharkia governorate. Assiut Vet. Med. J. Vol. 54 No. 119 October 2008

Elbestawy, A.R. (2010): Studies on Ornithobacterium rhinotracheale (ORT) and Mycoplasma gallisepticum infections in commercial chicken flocks in ElBehera and Kafr El-Sheikh Governorates. Proc. Proceedings of 9th Scientific Conference of the Egyptian Veterinary Poultry Association, Egypt. (Abstr.).

El-Gohary, A.A. and Awaad, M.H.H. (1998):

Concomitant

Ornithobacterium rhinotracheale

(ORT) and E. coli infection in broiler chickens. Vet. Med. J. Giza. 45: 67.

EL-Gohary, A. and Sultan, H. (1999): Ornithobacterium rhinotracheale (ORT): infection in meat-type breeder chickens. J. Alex. Vet. Sci. 15(2): 253-269.

EL-Gohary, A.; Sultan, H. and Hafez, H.M. (1998): Isolation of Ornithobacterium rhinotracheale (ORT) and Pasteurella Haemolytica from commercial larger chickens. In: Proceedings of 5th Scientific conference, Egypt Veterinary Poultry Association, 111-128.

Ellakany, H.; Elbestawy, A.R.; AbdElhamid, H.; Gado, A.; Nassar, A.; Abdel-Latif, M.; Ghanima, I.; ElHack, M.; Swelum, A.; Saadeldin, I.; Ba-Awadh, H. and Al-Owaimer, A. (2018): Effect of experimental Ornithobacterium rhinotracheale infection along with live infectious bronchitis vaccination in broiler chickens. Poultry Science 98. 1003382/ps/pey324.

Ellakany, H.F.; Elbestawy, A.R.; AbdElhamid, 1H.S.; Gado, A.R.; Nassar, A.A.; Abdel-Latif, M.A.; Abo Ghanima, I.I.; Abd El-Hack, M.E.; Swelum, A.A.; Saadeldin, II.M.; Ba-Awadh, H.A. and Alowaimer, A.N. (2019): Effect of experimental Ornithobacterium rhinotracheale infection along with live infectious bronchitis vaccination in broiler chickens. Poultry Science 98:105-111 http://dx.doi.org/10.3382/ps/pey324

Hafez, H.M. (2002): Diagnosis of Ornithobacterium rhinotracheale. International Journal of Poultry Science 1(5): 114-118.

Hafez, H.M. and Sting, R. (1996): Serological surveillance on Ornithobacterium rhinotracheale in poultry flocks using self-made ELISA. In Proceedings of the 45th Western Poultry Disease Conference, Cancun, Mexico, pp. 163-164.

Hassanzadeh, M.; Karrimi, V.; Fallah, N. and Ashrafi, I. (2010): Molecular characterization of Ornithobacterium rhinotracheale isolated from broiler chicken flocks in Iran. Turk. J. Vet. Anim. Sci. 34:373-378. 
Hegazy, A.M.; Hassanin, O. and Ismaeil, G.F. (2015): An experimental coinfection of broilers with local isolates of Ornithobacterium rhinotracheale and Escherichia coli. Zagazig Veterinary Journal, 43(3), 82-94.

Hung, A.L. and Alvarado A. (2001): Phenotypic and molecular characterization of isolates of Ornithobacterium rhinotracheale from Peru. Avian Dis. 45: 9991005.

Li, Y.Y. and Diao, Y.X. (2009): PCR method for Ornithobacterium rhinotracheale detection. Fujian Journal Agricultural Science, 1: 1923.

Mayahi, M.; Gharibi, D.; Ghadimipour, $R$. and Talazadeh, F. (2016): Isolation, identification and antimicrobial sensitivity of Ornithobacterium rhinotracheale in broiler chicken flocks of Khuzestan, Iran. In Veterinary Research Forum (Vol. 7, No. 4, p. 341). Faculty of Veterinary Medicine, Urmia University, Urmia, Iran.

Mohammad Hassanzadeh; Vahid Karrimii; Neda Fallah and Iradj Ashrafi (2010): Molecular characterization of Ornithobacterium rhinotracheale isolated from broiler chicken flocks in Iran. Turk. J. Vet. Anim. Sci.; 34(4): 373-378

Moursi, M.K. and Kawther H. Sabah (2008): Studies on chickens Ornithobacterium infection at Ismailia Province. Assiut Vet. Med. J. Vol. 54 No. 117 April 2008

Mousavi, S.M.; Hassanzadeh, M.; Khoshkhoo, P.H. and Azad, G.A. (2012): Detection and prevalence antibodies against Ornithobacterium rhinotracheale
(ORT) by ELISA in broiler chicken farms in Guilan province, Iran. Global Veterinary, 8(2), 133-138.

Nassar, A.A. (2017): Effect of experimental infection with Ornithobacterium rhinotracheale (ORT) spontaneously with a live infectious bronchitis vaccination of broiler chickens. M.v.sc. Thesis in Poult. Dis., Fac. Vet. Med. Damanhour Univ.

Ozbey, G.; Ongor, H.; Balik, D.T.; Celik, V.; Kilic, A. and Muz, A. (2004): Investigations on Ornithobacterium rhinotracheale in broiler flocks in Elazig Governorate located in the East of Turkey. Vet. Med. Czech. 49: 305-311.

Umali, D.V.; Shirota, K.; Sasai, K. and Katoh, $H$. (2018): IMMUNOLOGY, HEALTH, AND DISEASE Characterization of Ornithobacterium rhinotracheale from commercial layer chickens in eastern Japan. Poultry Science 97:24-29 http://dx.doi.org/10.3382/ ps/pex 254

Rahimi, M. and Banani, M. (2007): Isolation of Ornithobacterium rhinotracheale from the chickens of a broiler farm in Kermanshah province, west of Iran. Iranian Journal Veterinary Research, 8(4), 355-359.

Rubio, A.G. and Salazar, A.R. (2010): Identificación de Ornithobacterium Rhinotracheale (ORT) y Metapneumovirus Aviar (MA). Caracterizaçión Epidemiológica em Chile. Boletín Veterinário Oficial. Available online: https://www2.sag. gob.cl/Pecuaria/bvo/BVO_11_I_se mestre_2010/PDF_articulos/identifi cacion_ORT_MA.pdf (accessed on 23 July 2017).

Sambrook, J. and Fritsegh, E.F. Mentiates (1989): Molecular 
coloning. A laboratory manual. Vol. Cold spring Harbor Laboratory press, New York. Method validation for Aflatoxin MI determination in yoghurt using immune-affinity column clean up prior to high-performance liquid chromatography. Toxicol and health, 27(7), 629-35.

Shahata, M.A.; Abd El-Motelib, T.Y. and Hebat-Allah, A.M. (2006): Some studies on the incidence of Ornithobacterium rhinotracheale infection in chicken embryos and layers. Assiut Vet. Med. J. Vol. 52:110.257-243.

Van Empel, P.; Van Den Bosch, H.; Loeffen, P. and Storm, P. (1997): Identification and serotyping of Ornithobacterium rhinotracheale. J. Clin. Microbiol. 35: 418-421.

Van Empel, P.C.M. and Hafez, H.M. (1999):

Ornithobacterium rhinotracheale: a review. Avian Pathol. 28: 217-227.

Vandamme, P.; Segers, P.; Vancanneyt, M.; Van Hove, K.; Mutters, R.; Hommez, J.; Dewhirst, F.; Paster, B.; Kersters, K.; Falsen, E. and Mannheim, $\quad W . \quad$ (1994): Ornithobacterium rhinotracheale gen. nov., sp. nov., isolated from the avian respiratory tract. Int. J. Syst. Bacteriol. 44: 24-37.

Wu, H.; Diao, Y.; Li, Y.; Li, J.; Sun, J.; Liu, X. and Chen, L. (2010):

Isolation and identification of Ornithobacterium rhinotracheale. Journal of Northwest A \& F University- Natural Science Edition, 38(7), 1-6.

WHO (2002): World Health Organization, Department of communicable diseases surveillance and response. 


\section{عزل وتعريف ميكروب الاورنيثوباكتريم رينوتزاكيال من دجاج التسمين بالوادى الجديد وأسيوط}

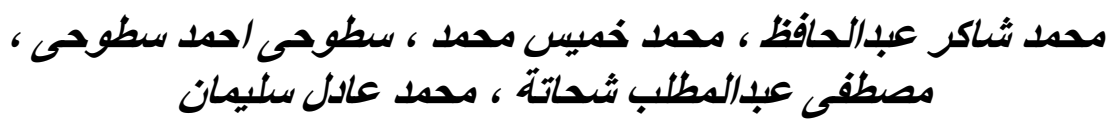

E-mail: drmohammed.abdelhafez@gmail.com Assiut University web-site: www.aun.edu.eg

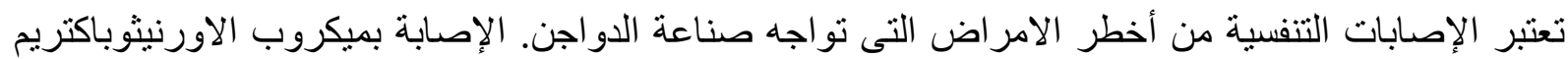

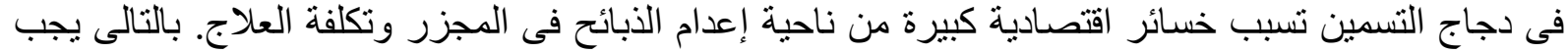

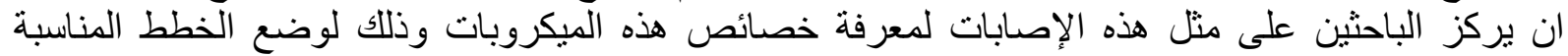

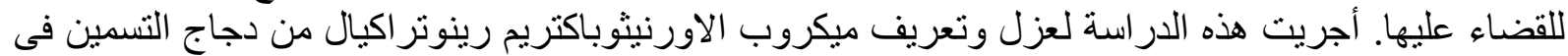

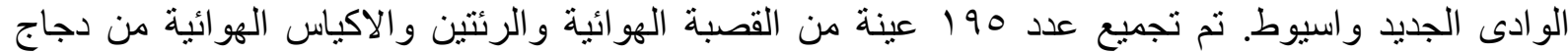

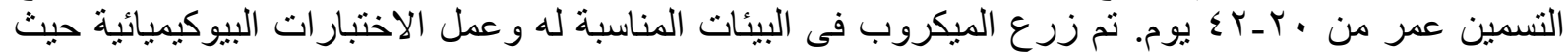

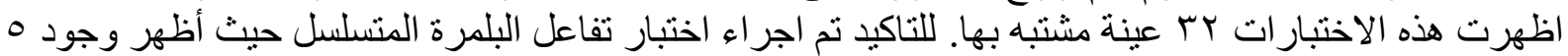

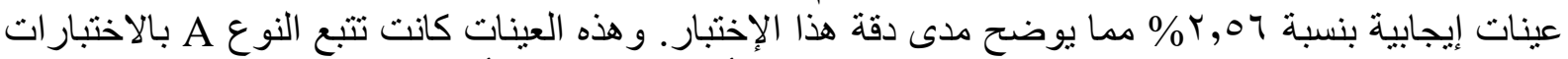

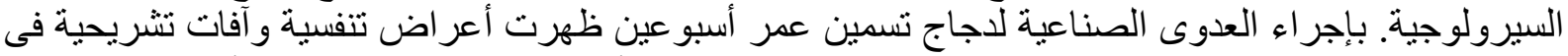
صورة إلتهاب القصبة الهوائية والرئتين وبعض التجبنات على الأكياس الهوائية. وكانت الأعراض واضن الصفة التشريحية أثند فى الاجاج المحصن ضد الند النيوكاسيل. 